\title{
RET Gene Amplification
}

National Cancer Institute

\section{Source}

National Cancer Institute. RET Gene Amplification. NCI Thesaurus. Code C133677.

A molecular genetic abnormality indicating the presence of multiple copies of the RET gene. 